CHILDREN AND FAMILIES

EDUCATION AND THE ARTS

ENERGY AND ENVIRONMENT

HEALTH AND HEALTH CARE

INFRASTRUCTURE AND

TRANSPORTATION

INTERNATIONAL AFFAIRS

LAW AND BUSINESS

NATIONAL SECURITY

POPULATION AND AGING

PUBLIC SAFETY

SCIENCE AND TECHNOLOGY

TERRORISM AND HOMELAND SECURITY
The RAND Corporation is a nonprofit institution that helps improve policy and decisionmaking through research and analysis.

This electronic document was made available from www.rand.org as a public service of the RAND Corporation.

Skip all front matter: Jump to Page $1 \nabla$

\section{Support RAND}

Browse Reports \& Bookstore

Make a charitable contribution

\section{For More Information}

\author{
Visit RAND at www.rand.org \\ Explore RAND Testimony \\ View document details
}

\section{Testimonies}

RAND testimonies record testimony presented by RAND associates to federal, state, or local legislative committees; government-appointed commissions and panels; and private review and oversight bodies.

\section{Limited Electronic Distribution Rights}

This document and trademark(s) contained herein are protected by law as indicated in a notice appearing later in this work. This electronic representation of RAND intellectual property is provided for noncommercial use only. Unauthorized posting of RAND electronic documents to a non-RAND website is prohibited. RAND electronic documents are protected under copyright law. Permission is required from RAND to reproduce, or reuse in another form, any of our research documents for commercial use. For information on reprint and linking permissions, please see RAND Permissions. 


\title{
The Role of Oil in ISIL Finances
}

\author{
Keith Crane
}

\section{RAND Office of External Affairs}

\section{CT-448}

December 2015

Testimony presented before the Senate Energy and Natural Resources Committee on December 10, 2015

This product is part of the RAND Corporation testimony series. RAND testimonies record testimony presented by RAND associates to federal, state, or local legislative committees; government-appointed commissions and panels; and private review and oversight bodies. The RAND Corporation is a nonprofit research organization providing objective analysis and effective solutions that address the challenges facing the public and private sectors around the world. RAND's publications do not necessarily reflect the opinions of its research clients and sponsors. RAND ${ }^{\circledR}$ is a registered trademark. 
Published 2015 by the RAND Corporation

1776 Main Street, P.O. Box 2138, Santa Monica, CA 90407-2138

1200 South Hayes Street, Arlington, VA 22202-5050

4570 Fifth Avenue, Suite 600, Pittsburgh, PA 15213-2665

RAND URL: http://www.rand.org/

To order RAND documents or to obtain additional information, contact

Distribution Services: Telephone: (310) 451-7002;

Email: order@rand.org 


\section{Keith Crane ${ }^{1}$ \\ The RAND Corporation}

\section{The Role of Oil in ISIL Finances ${ }^{2}$ \\ Before the Committee on Energy and Natural Resources United States Senate}

December 10, 2015

Thank you, Chairman Murkowski and Ranking Member Cantwell, for the opportunity to testify today on the role of oil in Islamic State in Iraq and the Levant (ISIL) finances.

\section{Financing Terrorists and Insurgent Groups}

RAND researchers have been actively engaged in research on the financing of terrorist groups and insurgencies for decades. This testimony is drawn from past RAND research and information from news reports, public government documents, and other researchers.

Unfortunately, the costs of perpetrating a terrorist attack are small. The bombings in Madrid in March 2004 and the London bombings of July 2005 cost about $\$ 80,000$ and $\$ 15,000$, respectively. ${ }^{3}$ Terrorists often finance these operations with their own resources or criminal activities. Oil plays little role in financing terrorist attacks because the costs of mounting these attacks are relatively low.

In contrast, insurgent groups like ISIL need substantial sums of money to finance their operations. According to General James Clapper, director of U.S. national intelligence, the intelligence community estimates that ISIL fielded 31,000 fighters in $2014 .{ }^{4}$ Others estimate that ISIL has as

\footnotetext{
${ }^{1}$ The opinions and conclusions expressed in this testimony are the author's alone and should not be interpreted as representing those of RAND or any of the sponsors of its research. This product is part of the RAND Corporation testimony series. RAND testimonies record testimony presented by RAND associates to federal, state, or local legislative committees; government-appointed commissions and panels; and private review and oversight bodies. The RAND Corporation is a nonprofit research organization providing objective analysis and effective solutions that address the challenges facing the public and private sectors around the world. RAND's publications do not necessarily reflect the opinions of its research clients and sponsors.

${ }^{2}$ This testimony is available for free download at http://www.rand.org/pubs/testimonies/CT448/.

${ }^{3}$ Whitlock, Craig, "Al Qaeda Masters Terrorism on the Cheap: Financial Dragnet Largely Bypassed," Washington Post, August 24, 2008, p. A01. As of February 17, 2009: http://www.washingtonpost.com/wp-dyn/content/story/2008/06/23/ST2008062302295.html ${ }^{4}$ Robert Windrem, "ISIS By the Numbers: Foreign Fighter Total Keeps Growing," NBC News, February 28 , 2015.
} 
many as 80,000 members. ${ }^{5}$ ISIL members have to be paid a salary. ISIL also has to pay for ammunition, weapons, and vehicles, as well as fuel and spare parts. It also pays for intelligence and security personnel, schools, and some health care in the areas it controls.

These expenditures add up. Members have reportedly been paid from $\$ 100$ to $\$ 1,000$ per month, although these figures have not been publicly confirmed by the group's own records. ${ }^{6}$ RAND researchers estimate that fighters, on average, have received $\$ 100$ per month. ${ }^{7}$ Syrian opposition groups and others estimate an average of $\$ 400$ per month. ${ }^{8}$ Foreign fighters do not receive a salary, only food and housing. ${ }^{9}$ A membership of 80,000 averaging $\$ 400$ a month in salary would have an annual wage bill of $\$ 384$ million, while a force of 31,000 with an average wage of $\$ 100$ per month yields an annual wage bill of about $\$ 37$ million. ${ }^{10}$ In addition, there are the salaries and costs for the leadership, media, police, education, and health care, and even death benefits. According to analyst Aymenn Jawad al-Tamimi, in January 2015 in Deir az-Zor province in Syria, which is under the control of ISIL, total monthly expenditures ran $\$ 5.6$ million, or about $\$ 70$ million on an annual basis. Of this figure, monthly salaries for fighters are the largest budgetary costs, amounting to 43.6 percent or about $\$ 30$ million a year. By comparison "base support" costs amount to 19.8 percent of total expenditures; media, 2.8 percent; Islamic Police, 10.4 percent; the Services Department, 17.7 percent; and aid to families 5.7 percent. ${ }^{11}$ Including all costs, IHS Jane's estimates monthly costs of roughly $\$ 80$ million or annual costs of close to $\$ 1$ billion. ${ }^{12}$

\footnotetext{
5 "Russian Intelligence Says ISIS Has 80K Militants in Iraq and Syria," Rudaw.net, October 11, 2015, at http://rudaw.net/english/world/101120152; and "Islamic State 'Has 50,000 Fighters in Syria,"' Al Jazeera, August 19, 2014.

6 "ISIS Pays Foreign Fighters \$1,000 a Month: Jordan King," NBC News, September 22, 2014.

${ }^{7}$ Benjamin W. Bahney, Radha K. Iyengar, Patrick B. Johnston, Danielle F. Jung, Jacob N. Shapiro, Howard J. Shatz, "Insurgent Compensation: Evidence from Iraq," American Economic Review: Papers \& Proceedings 2013, 103(3): 518-522.

${ }^{8}$ Erin Banco, "Syrian Opposition told US Senior Officials It Cannot Stop ISIS Without More Weapons," International Business Times, August 25, 2014; "The Economist Explains: Where Islamic State Gets Its Money," The Economist, January 4, 2015.

${ }^{9}$ Heather Saul, "Senior Isis leader gives televised interview revealing exactly how group amassed its fortune," Independent, April 23, 2015, accessed on December 7, 2015 at http://www.independent.co.uk/news/world/middle-east/senior-isis-leader-gives-televised-interview-revealingexactly-how-group-amassed-its-fortune-10196045.html.

${ }^{10}$ In earlier years most fighters received only $\$ 100$ per month. Foreign fighters do not receive a salary, only food and housing.

${ }^{11}$ Aymen Jawad al-Tamimi, "Unseen Islamic State Financial Accounts for Deir az-Zor Province," Jihadology.net, October 5, 2015, at http://jihadology.net/2015/10/05/the-archivist-unseen-islamic-statefinancial-accounts-for-deir-az-zor-province/.

12 “Islamic State Monthly Revenue Totals \$80 million, IHS Says," IHS Newsroom, December 7, 2105 accessed at http://press.ihs.com/press-release/aerospace-defense-security/islamic-state-monthly-revenuetotals-80-million-ihs-says on December 8, 2015.
} 
In addition to Deir az-Zor in Syria, ISIL also controls parts of Raqqa, Aleppo, and Idleb provinces. In Iraq, it controls most of Anbar and Ninevah provinces, and parts of Salaheddin. ${ }^{13}$ It is also active in Diyala and Kirkuk provinces. Deir az-Zor is an important province, and likely is representative of provinces under ISIL control. Assuming average expenditures per province elsewhere are equal to expenditures in Deir az-Zor, ISIL would be spending roughly $\$ 500$ million per year in total.

\section{From Where Does the Money Come?}

Insurgencies or, in this case, proto-states, need much more money than terrorist groups. However, since the end of the Cold War, insurgencies have been increasingly on their own when it comes to financing. ${ }^{14}$ Financial support from foreign governments or contributions from individuals have not been important sources of funding for insurgents in the Niger River delta and for Boko Haram in Nigeria, ISIL in Syria and Iraq, or the Revolutionary Armed Forces of Colombia (FARC). These groups finance themselves by taxing or trafficking in valuable commodities and by extorting money from the local population through "taxes," kidnapping, property theft, and threats to individuals and their families. The role of cocaine as a source of revenue for the FARC and of opium and heroin for the Taliban are cases in point.

In the case of ISIL, analysts and U.S. government officials have circulated a number of rough estimates concerning the group's revenues. ISIL revenues from the sale of oil and refined oil products ran at $\$ 40$ million in one month this year, which annualized comes to $\$ 480$ million per year. ${ }^{15}$ Oil and refined oil products are the single most important source of income for ISIL. Sales of antiquities pillaged from sites under ISIL control may bring in as much as $\$ 100$ million this year, although this number is an upper bound. ${ }^{16}$ Revenues from "taxes"; tolls; extortion payments from individuals, especially members of religious or ethnic groups targeted by ISIL; extortion from businesses; taking a share of salaries paid by the Iraqi government to its employees in ISIL territory; resale of stolen or expropriated cars; and similar sources of funding could run as much as $\$ 600$ million in $2015 .{ }^{17}$ In total, these estimates suggest total annual funding in 2015 of as much as $\$ 1.2$ billion.

\footnotetext{
13 "Two Arab Countries Fall Apart," The Economist, June14, 2014.

14 Daniel Byman, Peter Chalk, Bruce Hoffman, William Rosenau, and David Brannan, Trends in Outside Support for Insurgent Movements, Santa Monica, Calif.: RAND Corporation, MR-1405-OTI, 2001.

${ }^{15}$ Daniel Glaser, Assistant Secretary of Treasury, Aspen Security Forum, July 15, 2015.

${ }^{16}$ Presentation by the Ambassador of Iraq to the United Nations, April 2015.

17 Sarah al Mukhtar, "ISIS Finances Are Strong," New York Times, May 19, 2015.
} 
However, in 2015 the Iraqi government stopped making payments to civil servants and citizens in Mosul, depriving ISIL of an important source of funding. It has also lost oil fields, such as Ajil in Iraq. ISIL's revenues will fall further if it loses control of more oil fields, if more loading facilities and tanker trucks are destroyed, as occurred in the recent Tidal Wave II operation, if the international community puts on more pressure to halt trade in antiquities, and if people continue to flee territories controlled by ISIL and economic activity continues to decline. As of December 2015 , several of these conditions have come to pass, suggesting that ISIL revenues in 2016 will be lower than in 2015 .

However, ISIL has substantial amounts of cash on hand. At the beginning of 2015, ISIL may have had a strategic reserve of up to $\$ 2$ billion. This figure is based on $\$ 875$ million that ISIL reportedly had on hand before it invaded Mosul in summer 2014. After capturing Mosul, it plundered an estimated $\$ 1$ billion to $\$ 1.2$ billion from banks in the territory it took over, including $\$ 425$ million to $\$ 450$ million stolen from the Mosul branch of the Iraqi Central Bank, as well as funds from a number of other banks in other territories it seized in Iraq. ${ }^{18}$ Without continued revenues from oil, at current expenditure levels, these reserves would be consumed within five years.

\section{How Does ISIL Make Money from Oil?}

ISIL has captured the main oil fields in Syria. Its hold on Iraqi oil fields is now minimal. ${ }^{19}$ In the past decade, total Syrian production ran between 400,000 and 500,000 barrels per day, ${ }^{20}$ of which production from the main fields under ISIL's current control was about 300,000 barrels per day. ${ }^{21}$ However, the lack of technical knowhow and the overall chaos in Syria have prevented ISIL from maintaining production at previous levels. Currently, the production from these fields may run as low as about 40,000 barrels per day. ${ }^{22}$ Another source states that ISIL may be producing 50,000 barrels per day. ${ }^{23}$

Crude oil is not useful until it has been refined. Entrepreneurs in ISIL-controlled territory have set up small "teapot" refineries, unsophisticated operations that heat the crude oil to separate out low-quality gasoline and diesel, which are then sold locally. These entrepreneurs are reportedly

\footnotetext{
${ }^{18}$ Glaser, 2015.

${ }^{19}$ Ben Lando, "Q\&A: Oil Minister Adil Abd al-Mahdi - Part 1," Iraq Oil Report, December 8, 2015.

${ }^{20}$ U.S. Energy Information Administration, "Table: Total Oil Supply (Thousand Barrels Per Day)," web page, accessed on December 7, 2015 at http://www.eia.gov/cfapps/ipdbproject/IEDIndex3.cfm?tid=5\&pid=53\&aid=1\#.

${ }^{21}$ Matthew M. Reed, "Taking Stock of ISIS Oil: Part 1," The Fuse, October 23, $2015 \mathrm{a}$.

22 Erika Solomon, Guy Chazan, and Sam Jones, "Isis Inc: How Oil Fuels the Jihadi Terrorists," Financial Times, October 14, 2015; Glaser, 2015.

${ }^{23}$ Matthew M. Reed, “Taking Stock Of ISIS Oil: Part 2,” The Fuse, October 29, $2015 \mathrm{~b}$.
} 
the most important buyers of oil from ISIL-controlled fields. Some oil finds its way to the Syrian government through intermediaries. One source estimates that the Syrian government purchases as much as 20,000 barrels per day from ISIL-controlled fields for its refineries through intermediaries. ${ }^{24}$ Iraq, including the Kurdistan Region of Iraq and disputed territories; Turkey; and parts of Syria not controlled by ISIL have been reported to be destinations for smuggled refined oil products from the small refineries in ISIL-controlled territories; neither Iraq nor Turkey appears to be important destinations for crude oil. ${ }^{25}$

Like almost all goods in Syria, all the crude oil and refined oil products under the control of ISIL are transported to buyers by truck. Before the civil war, Syria had a substantial trucking industry consisting of both fleet operators and owner-operators. The trucks that transport oil from ISILcontrolled territories are owned by these businesses. The drivers of these trucks may be the owner-operators or hired by fleet operators.

\section{Policies to Reduce Funding for Insurgencies}

Armies march on their stomachs. Without funds to pay for food, wages, and ammunition, insurgencies are hobbled as commanders are unable to launch and sustain operations. A major reason that guerrillas in El Salvador agreed to come to the negotiating table in 1991 was the end of financial and logistical support from the Soviet Union. ${ }^{26}$ In the case of ISIL, previous RAND research has shown a direct correlation between the level of spending and the pace of attacks by its predecessor group, al-Qa'ida in Iraq. ${ }^{27}$

Although ideology, especially in the case of ISIL, is the primary motivation for individuals to join insurgencies, commercial activities associated with insurgencies, like cocaine production and smuggling in Colombia or opium and heroin production in Afghanistan, can become so lucrative that they become an important motivation for some individuals engaged in insurgencies. Commercial motivations can become so entrenched that some insurgent groups keep fighting even after material motivations have replaced ideological or religious motivations.

\footnotetext{
${ }^{24}$ Reed, 2015b.

${ }^{25}$ Reed, 2015b.

${ }^{26}$ James Dobbins, Seth G. Jones, Keith Crane, Andrew Rathmell, Brett Steele, Richard Teltschik, and Anga Timilsina, The UN's Role in Nation-Building: From the Congo to Iraq, Santa Monica, Calif.: RAND Corporation, MG-304-RC, 2005, p. 45.

${ }^{27}$ Benjamin Bahney, Howard J. Shatz, Carroll Ganier, Renny McPherson, and Barbara Sude, An Economic Analysis of the Financial Records of al-Qa'ida in Iraq, Santa Monica, Calif.: RAND Corporation, MG-1026OSD, 2010.
} 
For these reasons, policies designed to reduce funding for insurgencies can have substantial payoffs in terms of fewer resources for military operations and a reduction in commercial motivations to keep the insurgency going. To reduce ISIL revenues from oil, the U.S. government has been targeting oil field facilities, such as loading depots, and tanker trucks. It could also impose financial sanctions on businesses in the region engaged in transporting and trading oil and refined oil products sold by ISIL, like truck fleet operators and intermediaries for the Syrian regime or on any other buyers of ISIL oil. The U.S. government could also impose sanctions on banks that provide financial services for individuals and businesses associated with ISIL or businesses that engage in commercial activities, like the oil trade, that serve ISIL's needs. This would include banks that do businesses with ISIL-associated money exchanges (hawalas), which might be beyond the reach of current U.S. sanctions laws. The U.S. government could also use oil-trading network analysis to locate and neutralize ISIL oil leadership, as it did earlier this year with ISIL oil emir Abu Sayyaf.

\section{How Effective Are These Measures Likely to Be?}

In an effort to reduce ISIL revenues, the United States has been targeting oil infrastructure, including oil loading and other facilities in oil fields controlled by ISIL, and tanker trucks hauling oil from these fields to buyers. To discourage truckers from hauling crude oil or refined oil products, the United States has leafleted truck drivers to inform them that trucks will be targeted. ${ }^{28}$ The United States destroyed over a hundred trucks in its first campaign, using bombs and largecaliber machine guns on A-10 Warthogs. These trucks were sitting empty, waiting their turn to be filled at loading stations. The combination of hitting oil infrastructure and tanker trucks appears to have made a major dent in ISIL oil revenues, at least for the time being. However, despite these operations, truckers have not yet completely stopped hauling crude oil or refined products.

How effective has this tactic been, and is it likely to be effective in the future? Hitting trucks remains a good tactic. Trucks are expensive. New heavy trucks cost over $\$ 100,000$. Even used trucks cost tens of thousands of dollars. For any trucking business in Syria, the loss of a heavy truck would inflict a substantial financial blow. Repeated losses would eventually force the company out of business. Thus, destroying heavy trucks transporting crude oil or refined oil products should lead to a decline in the number of trucks available and hence revenues for ISIL.

Income is hard to come by in Syria; there has been no lack of individuals willing to drive trucks into ISIL-controlled territory to transport crude oil, refined oil products, or other cargos. For many,

\footnotetext{
${ }^{28}$ Michael R. Gordon, "U.S. Warplanes Strike ISIS Trucks in Syria," New York Times, November 16, 2015.
} 
if not most, of these individuals, hauling oil is a commercial, not an ideological decision. Targeting trucks, even after warning drivers that they are targets, may lead to the death of some truck drivers.

Targeting oil infrastructure is also likely to lower ISIL oil revenues. This is particularly true of any infrastructure that facilitates the transfer of crude oil from the wellhead to trucks, and of any infrastructure that is expensive to replace or takes time to rebuild. While destroying a storage shed at an oilfield is unlikely to have an effect, destroying a fuel oil separator or a pumping station is likely to impair revenue flows.

Imposing financial sanctions on larger businesses_and their banks_-in the region engaged in transporting and trading oil and refined oil products sold by ISIL should have a tangible, if modest effect on ISIL. Larger businesses need banking services. Moreover, business that involves ISIL is almost certainly only part of their operations. A concerted effort on the part of the U.S. Treasury to target larger businesses and their banks would likely reduce or stop their engagement with ISILaffiliated activities, raising costs for ISIL.

Imposing sanctions on banks that provide financial services for businesses engaged with ISIL would reduce access to financial services for these enterprises, also raising costs for ISIL as the number and willingness of businesses to engage with it would decline.

Because of the severity of the punishments it inflicts and the extreme ideological positions it adopts, ISIL can be difficult to penetrate. Using oil trading networks to garner information about ISIL provides another avenue for locating the leadership.

These measures will not lead to the financial demise of ISIL. As noted above, ISIL draws on sources of income other than oil to finance its operations. Oil and refined oil products are valuable enough that light trucks, even pickups, can be used to haul smaller quantities, albeit more expensively and less efficiently than heavy trucks. The United States and its allies would be unable to target large numbers of light trucks hauling oil or refined oil products. Because light trucks are ubiquitous in Syria, targeting them could lead to civilian casualties without much effect on ISIL's overall financial revenues.

ISIL operates heavily on cash, so measures targeting financial services although helpful will not lead to a total cutoff in funds. Smaller businesses that engage with ISIL are too small for the U.S. Treasury to target. In addition, those located on territory controlled by ISIL are subject to coercion, making it almost impossible for them to refuse to conduct business with ISIL. 


\section{Conclusions}

Measures to reduce funding for ISIL are an important component of a strategy to degrade ISIL and end its control of territories in Iraq and eventually Syria. Revenues from sales of oil and refined oil products are the most important single source of recurrent revenues for ISIL. Provided the tactic is sustained, targeting oil loading facilities and heavy trucks hauling crude oil and refined oil products is a useful tool to reduce ISIL revenues. Although this tactic alone will not lead to the demise of ISIL, it can weaken it.

Thank you Chairman Murkowski, Ranking Member Cantwell, and members of this committee for the opportunity to testify before you this morning. I look forward to answering your questions. 